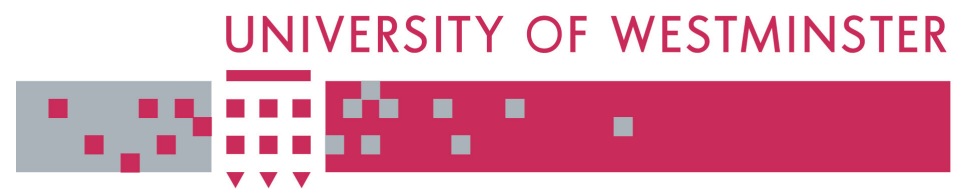

\author{
WestminsterResearch \\ http://www.wmin.ac.uk/westminsterresearch
}

Have the major forces driving leisure airline traffic changed?

Anne Graham

School of Architecture and the Built Environment

This is an electronic version of an article published in Journal of Air Transport Management, 12(1), pp. 14-20, January 2006. Journal of Air Transport Management is available online at:

http://www.elsevier.com/locate/jairtraman

The WestminsterResearch online digital archive at the University of Westminster aims to make the research output of the University available to a wider audience. Copyright and Moral Rights remain with the authors and/or copyright owners. Users are permitted to download and/or print one copy for non-commercial private study or research. Further distribution and any use of material from within this archive for profit-making enterprises or for commercial gain is strictly forbidden.

Whilst further distribution of specific materials from within this archive is forbidden, you may freely distribute the URL of WestminsterResearch. (http://www.wmin.ac.uk/westminsterresearch).

In case of abuse or copyright appearing without permission e-mail wattsn@wmin.ac.uk. 


\title{
HAVE THE MAJOR FORCES DRIVING LEISURE AIRLINE TRAFFIC CHANGED?
}

\author{
Dr Anne Graham \\ University of Westminster
}

\begin{abstract}
The purpose of this paper is to examine the major forces which are driving leisure airline traffic and to assess whether these have changed in recent years. Initially this is undertaken by considering global patterns of airline and tourism demand and then by a more detailed investigation of the UK situation. The research indicates that airline demand is becoming less sensitive to income changes and also that the share of income spent on air travel is not showing much growth. Both of these suggest that airline demand may be becoming more mature, with growth being increasingly driven by price reductions rather than income changes. Moreover evidence from the UK shows that changing customers preferences, and subsequent industry developments to accommodate these, appear to be having a significant impact on the demand for different types of leisure air trips.
\end{abstract}

\section{Introduction}

Since the demand for air transport is derived, it is the nature of the demand for the overall tourism product or destination which will ultimately determine the volume and type of leisure traffic carried by airlines. The general forces which drive leisure travel demand can be divided between determinants and motivators (Swarbrooke and Horner, 1999). Determinants are factors which make it possible for people to travel. These can be related to economic and social conditions (such as income, leisure time) and conditions set by the providers of tourist services (i.e. price, quantity and quality of the product). Motivators are factors which make the consumer willing to travel and these will be related to personality traits and attitudes, and may be influenced by the promotional activities of the providers. These are likely to be affected by socioeconomic and demographic characteristics of the consumer.

Determinants and motivators can be considered within a long-term or short-term horizon. For example, strong overall economic growth in the last decade or so in a number of South East Asian countries has been an important determinant in producing higher than average outbound tourism growth. Meanwhile in the more short-term the terrorist attacks of $9 / 11$ reduced tourist motivation in certain markets because of safety and security concerns. Strategic behaviour by airlines and other operators within the tourism industry in reaction to one-off short-term events may also have a significant short-term, and perhaps longterm, impact on demand in affecting both the product, its price on offer and 
the consumers' attitude towards it. For this paper the focus is very much on the long-term.

In most developed countries, holiday travel is by far the most important type of travel and it represented 68 per cent of all travel undertaken by Europeans in 2003 and 79 per cent of all leisure trips (IPK International, 2004). The other main type of leisure travel is Visiting Friends and Relatives (VFR). To some extent key determinants such as leisure time and income are shared between holiday and VFR travel. Other factors, such as ethnic links or mobility of labour may be peculiar to VFR traffic. Also there is no obligation to undertake holiday travel although there may be strong pressures to do so. However certain VFR travel, for example, visiting an elderly relative, could very well be defined as a 'necessary' trip which may have to be taken irrespective of economic and other factors which normally influence holiday travel.

An assessment of determinants and motivators needs to be accompanied by consideration of the specific role which air transport plays within leisure travel and the multiple levels of product substitution which exist (Brons et al, 2002). At the most general level, leisure travel can compete with other home-based leisure activities and the purchasing of travel products can be seen as just one of many spending options which consumers have with their disposable income. Then mode of transport substitution needs to be examined. The choice of mode of transport and whether air transport is used will depend on a multitude of different factors such as the length and time of the journey, the fares and range of services offered, service quality and level of competition. There is also destination substitution. Whether domestic or international trips and short-haul or long-haul trips are favoured will clearly be very important in determining the relative significance of air travel. Finally, at a more disaggregated level, substitution between different individual air carriers or different types of carriers (such as network, low cost and charter) needs to be considered. Additionally there may be other substitution effects within leisure travel concerning length or type of trip which may have consequences for air travel such as substituting more frequent short break travel for a less regular longer holiday. It is particularly important to appreciate these different levels of substitution in order to be able to assess whether the demand for air travel is newly generated or whether it has been merely shifted from another product or type of trip.

\section{Trends in Leisure Travel}

\subsection{Determinants}

Economic growth has historically been a key determinant of leisure travel demand and it continues to play an important role in many forecasting models. The traditional 'rule of thumb' measure for general air transport markets is that the GDP multiplier is around two - this assumes that demand will grow or decline twice as fast as any change in GDP (Doganis, 2002). Looking at the total global air transport market (since separate leisure data is not available) it may be seen that the GDP multiple has been in the range of 1.5-2.2 since 1970, if abnormal events since 2000 such as 9/11 and SARS 
are excluded, and so appears fairly close to the rule of thumb figure (Figure 1, Table 1). Likewise Boeing is predicting an average GDP multiple of 1.7 for the next 20 years (Boeing, 2004). By contrast, overall international tourist arrivals (since only international data for all travel purpose is available) appear less sensitive to income changes with a GDP multiple of around 1.3-1.4.

A key issue is to what extent, if any, does the relationship between income and travel growth demonstrate any movement towards market maturity. There are two key dimensions to this, namely the degree to which income produces proportionally larger increases in demand and also the extent to which the relationship with income changes through time. A totally mature market could be defined as one which grows by no more than the economic growth. Globally, with the limited evidence which is available, this does not appear to be the case with either total air transport or tourism demand. However it needs to be noted that the tourism data excludes domestic tourism which in most cases is thought likely to be a more 'mature' type of travel. By contrast the declining sensitivity to income changes, as observed with the air transport multiplier from 2.2 to 1.5 , could indicate that the market is moving towards maturity. For tourism the multiplier remains relatively unchanged.

A fundamental weakness in comparing travel growth solely to economic growth is that it ignores the important influence that travel cost or price can play. The travel cost will determine the amount of income that needs to be spent on travel and can be divided into two separate elements, namely the cost of travel to and from the destination (i.e. the transport cost) and the cost of living at the destination. This in turn will be affected by factors such as exchange and inflation rates. For some intra-regional travel, the influence of the cost of travel to and from the destination may often be relatively small compared with the destination cost. For some long-haul trips, however, the cost of travelling to the destination may be as great or even greater than the cost of staying at the destination.

For the consumer, it is clearly the total travel cost which is of most relevance. Thus an alternative definition of total maturity could be when changes in income cease to produce proportionally large changes in travel spend or, in other words, when travel spending represents a constant share of income. A market which is moving towards maturity could likewise be represented by declining growth rates in the travel share value. In this case there could be considerable growth in tourist numbers stimulated by lower fares rather than economic growth but the tourists will have reached some limit in terms of the amount of income which they allocate to travel.

Within tourism this is a difficult area to explore at an aggregate level because most tourist spending data excludes spending on fares and hence does give a total picture. This is a very significant shortcoming as in recent years it is the costs associated with fares (and particularly with air transport), more than any other part of the tourism product, which have changed the most. Whilst acknowledging this limitation, it is still interesting to observe that without the fares data, it appears that the spending share of GDP on tourism has increased over the years and that the growth rates of this ratio do not seem to 
be decreasing which could have indicated a movement towards maturity (Figure 2 and Table 1).

Globally with the air transport industry, airline yield in real terms has fallen by over 50 per cent since 1970 (Doganis, 2002). This means that although there has been considerable growth in passenger-kms, a comparable rise in revenues has not been experienced. This airline revenue growth rather traffic growth in many ways is more useful for airlines as of a measure of demand and increased business (Sentance, 2001). If airline revenue is measured as a proportion of GDP, it may be seen that the share of spending on air transport has increased relatively little since 1980 (Figure 2, Table 1). Thus, in spite of the poor comparability of the tourism and airline datasets, the combined results appear to suggest that air travel is representing a decreasing share of tourism spending but that the total tourism spending share is continuing to rise - at least in terms of international travel.

Another important determinant, in addition to income and price, which has traditionally played a major influencing role on leisure travel, is the availability of leisure time. This is a complicated factor to explore but it is clear that the so-called 'leisure society' which was being predicted a few decades ago for the 21 st century has not really materialised. Whilst holiday entitlements at work may have increased, greater work pressures and fears about job security have meant that many employees are reluctant to take their full holiday allowance. This has also led to people not wanting to be away from work for long periods and has thus contributed to the trend towards shorter holidays which has been observed in many western economies. Other factors, such as more flexible working conditions and increased difficulties in cocoordinating holiday time for the growing number of couples who are both in full-time employment, have also contributed to shorter holidays and short breaks. Modal substitution may be more of a relevant issue in this situation as a time saving, which can be gained by travelling by air rather than by car or by taking a high speed train, is likely to be more important when the overall length of holiday is shorter.

Lower fares have meant that more frequent shorter holidays are not necessarily a more expensive option and the trend towards more flexible booking arrangements has encouraged this development. However with many 'cash-rich' and 'time-poor' societies it could be argued that the limiting factor to travel is more likely to be time rather than money. Following this logic, maturity could alternatively be defined as when the number of tourists-nights as a share of available leisure time becomes constant - but in practice this is very difficult to measure.

No matter in what way maturity is considered, clearly it is only a concept which has relevance in countries which already have a high level of travel participation and where most growth comes from existing tourists taking additional trips. It thus may be appropriate for the USA where citizens make an average of 2.2 air trips per year but not for India and China where only 0.02 and 0.06 trips respectively are made (Airbus, 2004). However even within Europe there is a considerable difference in travel participation with 
countries such as Germany, Luxembourg and the Netherlands where around 70-80 per cent of all residents take at least one long holiday a year. In contrast, in Spain and Portugal the participation rate is only around a third (Schmidt, 2003). In terms of just international trips (which in many countries may be more relevant when air travel is being considered) Austria, the Netherlands, Sweden and Switzerland have the highest travel propensities and so are perhaps the most suitable markets for consideration of maturity of leisure air travel (Graham and Humphreys, 2002).

Moreover within the population of each country, there will be many different consumer life style or life stage segments which will have different levels of travel participation and different relative availabilities of leisure time and income for travel. A notable example is the so-called 'grey' or over 55s market. The share of the population represented by this age group is set to rise as the baby boomers of the 1950s reach this life stage. In recent years leisure travel by this market segment has grown considerably, not only because people in this group are relatively time-rich, but also they are wealthier, healthier and more experienced travellers than before. However maintaining these living standards looks as if it is going to be increasingly hard to achieve in the future because of the difficulties of relying on a decreasing size of workforce to support a growing retired population living on pensions.

A final determinant worthy of particular consideration is supply constraints as these are likely to grow in significance as leisure travel increases. These constraints may be associated with the air transport industry such as a lack of runway slots, insufficient terminal capacity or airspace congestion, or elsewhere, for instance, with a lack of hotel beds. Sometimes these supply limits, such as a ban on hotel development or night time flying, may be artificially imposed due to environmental pressures and it is likely that such limits will increase in number as the aviation and tourism industry find the need to work at becoming more sustainable. In addition the introduction of taxes or charges to cover the environmental cost of travelling to, or staying at, the destination, may also limit the growth in demand for travel by pushing up the cost.

\subsection{Motivators}

In many western societies, growing experience of travel, better education and changes in family structure, life style and life stage (e.g. smaller families later in life, more single travellers or one-parent families) have meant that there has been a marked broadening of the range of requirements for the holiday product. This has meant that there has been a growth in demand for adventure, cultural and special interest holidays and demand for new destinations, particularly long-haul.

Greater flexibility, which is already apparent in the trend towards holidays of different and shorter length, is also a key driver in encouraging independent rather than package tours, growth in internet sales and less advance booking. In addition, there has been an increase in consumers owning second homes 
and requiring more flexible transport arrangements to visit these. All of these developments have meant that the future role of low cost carriers and charter airlines has been one of the most fiercely debated topics of recent years (Pilling and O'Toole, 2004; Williams, 2001; Buck and Lei, 2004). In general tourists are considered to more demanding and are increasingly expecting their holiday experience to be more personalized and to be more related to their individual life style and choice. Attitudes to travel may also be changed by supply constraints. These may not actually physically make the consumer unable to travel but they may reduce their desire to travel. For example, travellers may shy away from airports which are too congested or from resorts which are too crowded.

Motivators as well as determinants may play a key role in influencing market maturity. Maturity may occur not so much when consumers cannot afford to take more holidays, or have no more free time to do so, but rather when they have no desire to spend more money or time to travel any more. It is extremely likely that as the number of holidays taken by a tourist increases, that the desirability to take additional holidays will decrease. Thus the desire to travel would follow the law of diminishing marginal utility with the utility from consuming additional units declining as the rate of consumption increases. If this is the case at some stage the consumer will have a greater preference to spend their money or time in other ways rather than to travel more.

As total air travel demand has been increasing at a faster rate than the demand for all tourism, it now accounts for a larger global market share as is demonstrated in Table 2. At this global level it is very difficult to assess to what extent this growth is 'new' demand and to what extent it has been caused by modal substitution. Traditionally in many markets a shift to air transport was often due to travellers becoming wealthier and more able to purchase the more costly air transport product. However with the reduction in real prices, and particularly with the emergence of the low cost carriers (LCCs), the economic balance between air travel and other transport modes has changed. This has made the whole issue of modal substitution that more complex. Changing preferences and attitudes can also play a major role not only in stimulating new travel, but also in terms of substitution. Obvious examples are shifts from domestic to international or shifts from short-haul to long-haul as tourists become more adventurous.

\section{Case Study: The United Kingdom}

Having identified some general issues related to the generation of leisure airline traffic, this paper now investigates these further by considering the specific case of the United Kingdom. Only holiday travel is considered which has consistently accounted for over 80 per cent of all international air travel by UK residents in recent years. Most noticeably there has been a very significant shift from domestic to international holiday-taking with international holidays accounting for only 14 per cent in 1970 but increasing to over half of all holidays by the end of the last century - albeit that this only relates to holidays of 4+nights because of data limitations (Graham, 2000). In the early years it is generally considered that there was some direct substitution 
between domestic and international travel as international travel and particularly package tours became affordable and accessible to a growing share of the population. A beach holiday in an English coastal resort was replaced by a beach holiday in Spain. However the situation now appears more complex, with the domestic and international products offering different benefits to consumers and so to a certain extent the two types of holiday no longer compete head on. Another significant long-term trend has been that international holiday air travel has increased at the expense of sea and tunnel travel, namely from 68 per cent in 1990 to 80 per cent in 2004, albeit that there has been quite a considerable amount of variation in the air share over the individual years (Table 3).

In order to investigate market maturity, growth has been compared with consumer expenditure (CE) which is better measure of personal income than GDP when the data is available. It may be seen that the CE multiple is considerably greater than one for international travel, but smaller in size since 1980, and when all holidays (including domestic) are considered the sensitivity to income changes is much less (Table 4). But again such crude assessments cannot differentiate between the influences of income and travel cost. However both BAA and the Department for Transport produce more complex econometric forecasts which model the impact of income and cost on air international leisure demand. Based on their analysis they both consider the leisure market to be becoming more mature and they build this into their forecasts by assuming declining income elasticities (Civil Aviation Authority, 2002; DETR, 2000).

Looking at market maturity from the alternative spending viewpoint it is apparent that, as with the global trends, the air transport share of CE has not changed very much whereas the spending share at the international destination continues to rise (Figure 3). Whilst comparable total spending on all holidays (including domestic) is not available for the whole time period, previous research has indicated that the travel spending share for all holidays is more constant. This suggests that the overall holiday market may be becoming mature but still international air trips may be growing at the expense of other types of travel (Graham, 2000).

Turning now to the possible impact of changing consumer preferences, it is interesting to observe that the share of long-haul travel increased in the 1990s to account for a quarter of all trips by the late 1990s - but has subsequently fallen (Table 3). This latter development is primarily due to the growth of the low cost carriers which only serve short-haul markets and events such as 9/11 and the outbreak of SARS which had a greater impact on long-haul than short-haul traffic. In terms of travel arrangements, there is clearly a trend towards booking independently with package tours peaking at 63 per cent in 1994 but decreasing to only 48 per cent in 2004 (Table 3). Again much of this can be attributed to the growth of the low cost carriers. The average length of trip has decreased, from 12.0 days in 1991 to 10.2 days in 2003 (Table 3). This may be partly explained by the growth in short breaks abroad which accounted for 12 per cent of all holidays in 1999 but 15 per cent in 2003, with the proportion of UK residents taking three or more holidays in this time period 
increasing from 17 per cent to 32 per cent (Mintel, 2004). Finally in terms of travel distribution by age the International Passenger Survey also shows that the proportion of trips taken by residents over 55 years has increased from 17 per cent of all trips in 1994 to 22 per cent of all international trips in 2003. Thus all these developments appear to indicate that changing consumer preferences and life stages, and subsequent industry developments to accommodate these, are indeed having some significant impact on the nature of leisure travel - at least for UK residents.

Even though the long-term evidence to support the view that UK leisure air travel is moving towards maturity may not be conclusive, a key question is whether substantially lower cost travel, as made possible by the low cost carriers, can reverse or postpone any trends towards maturity, by enabling sectors of the population who were previously not travelling by air to travel, or by encouraging infrequent travellers to travel more. This needs consideration of the extent to which LCCs actually generate new traffic rather than merely shifting traffic from other carriers which is a much debated issue. Dennis (2004) made a rough estimate of the impact of low-cost carriers between 1998 and 2001 in the UK by using AEA average growth rates. During this period conventional scheduled airlines operating to/from the UK traffic grew by about 7 million passengers short of the expected figures based on AEA growth rates. Similarly charters were 1 million passengers short. Assuming that these 8 million passengers were carried by the LCCs this left a residual of 5 million of the 13 million passengers, carried by the LCCs which could assumed to be generated traffic.

BAA have reached fairly similar conclusions, estimating that the proportion of new passengers varies by route from 33 per cent to 66 per cent and perhaps averaging 50 per cent overall (Civil Aviation Authority, 2003). The UK Department for Transport has identified some destinations such as Barcelona, Madrid, Geneva and Nice where there has been a substantial amount of generated traffic, other destinations (e.g. Amsterdam, Frankfurt) where there has been some generated traffic but more substitution taking place and finally other more 'mature' routes (e.g. Brussels, Zurich, Dusseldorf, Copenhagen, Milan) where the amount of generated traffic has been much smaller (Department for Transport, 2003). However overall it is difficult to draw firm conclusions on the generation of traffic because these markets may have been targeted by the new entrants because they had growth potential anyway and also the new generated traffic may actually just have switched from a nearby airport or from another transport mode.

Within this context it is interesting to consider the traffic distribution by socioeconomic group of leisure travel at London airports in 1996 and 2003 which is the period which saw the emergence and high growth of the LCC sector. At all four airports, the wealthiest and most professional groups $A / B$ accounted for a disproportionately large amount of the traffic and the poorest groups D/E accounted for very small amounts which is as expected (Figure 4). However between 1996 and 2003 the share of traffic from the A/B groups increased at all airports, including both Luton and Stansted which experienced a huge growth in the amount of LCC traffic. Likewise at these two airports the 
proportion of trips taken by the next wealthiest group $\mathrm{C} 1$ also increased whilst the share for the other less affluent groups decreased. Therefore this does not provide strong evidence to suggest that the LCCs are appealing to the less wealthy parts of the population that have not travelled very much by air before. Instead they seem to be encouraging more frequent flying - perhaps in some instances influenced by the existence of a second home.

\section{Conclusions}

In conclusion, it is certainly true that in the last few years the environment within which the airline and tourism industries operate has become that much more less certain and stable. However in the long-term it seems likely that traditional key drivers of demand such as income, cost and time will continue to play an important role in influencing demand - although the exact relationship that they have with travel growth and their relative importance may well change. In less developed economies it is likely that economic growth will still play a significant role in stimulating travel growth of new travellers beyond the level of GDP growth, whereas in more developed countries travel cost is likely to have a far greater impact in encouraging additional trips. Moreover consumer preferences certainly seem to be changing the type of the leisure trip which is undertaken and the way in which it is booked.

As the air transport and tourism industries continue to develop, limits to growth are likely to become more significant. These limits may be due to supply constraints or market maturity and are made more complex by the multiple level of travel product substitution which exists. This paper has briefly discussed some of the concepts related to this but further investigation will be needed in the future as such issues become more and more relevant.

\section{References}

Airbus (2004), Global market forecast 2004-2023, Airbus

Boeing (2004), Current market outlook 2004, Boeing

Brons, M., Pels, E., Nijkamp, P. and Rietveld, P. (2002), Price elasticities of demand for passenger air travel: a meta analysis, Journal of Air Transport Management, 8, 165-175

Buck, S. and Lei, Z. (2004) Charter airlines: Have they a future? Tourism and Hospitality Research, 5 (1), 72-78

Civil Aviation Authority (2002) Annex: Review of BAA's traffic forecasts in Heathrow, Gatwick and Stansted Airports' Price Caps, 2003-2008: CAA recommendations to the Competition Commission, CAA

Civil Aviation Authority (2003) Air passenger growth and airport capacity: Advice to the Department for Transport on the future nature and distribution of demand for air travel, CAA 
Dennis, N. (2004) Can the European low-cost airline boom continue? Implications for regional airports. $44^{\text {th }}$ European Congress of the Regional Science Association, Porto, August

Department for Transport (2003) Air passenger growth and airport capacity: A technical discussion paper, DfT, April

DETR (now Department for Transport) (2000) Air traffic forecasts for the United Kingdom 2000, DETR

IPK International (2004), Global travel trends, press release, March 15

Doganis, R. (2002) Flying Off Course, third edition, Routledge

Graham, A. (2000) Demand for leisure air travel and limits to growth, Journal of Air Transport Management, 6, 109-118

Graham, A. and Humphreys C. (2002) International outbound statistics: A practical analysis of the major tourism origin countries, Sixth International Forum on Tourism Statistics, September, Budapest.

Mintel (2004), Short breaks abroad - UK, Mintel, June

Pilling, M. and O'Toole, K. (2004) Consumer power, Airline Business, December, 60-62

Sentance, A. (2001) Living with slower growth, Airline Business, July, 76-78

Schmidt, H. (2003), More holidaymakers and more holidays, Statistics in Focus, Eurostat Theme 4, 29

Swarbrooke, J. and Horner, S. (1999) Consumer behaviour in tourism, Butterworth-Heinemann.

Williams, G. (2001) Will Europe's charter carriers be replaced by 'no-frills' scheduled airlines? Journal of Air Transport Management, 7, 277-286 
Table 1: Long-Term Growth in Tourism and Air Transport Demand compared with GDP 1970-2004

\begin{tabular}{|l|c|c|c|c|}
\hline & $\mathbf{1 9 8 0 / 1 9 7 0}$ & $\mathbf{1 9 9 0 / 1 9 8 0}$ & $\mathbf{2 0 0 0 / 1 9 9 0}$ & $\mathbf{2 0 0 4 / 2 0 0 0}$ \\
\hline $\begin{array}{l}\text { AVERAGE } \\
\text { ANNUAL } \\
\text { CHANGE (\%): }\end{array}$ & & & & \\
\hline $\begin{array}{l}\text { International } \\
\text { Tourist Arrivals }\end{array}$ & 5.6 & 4.7 & 4.2 & 2.6 \\
\hline $\begin{array}{l}\text { World } \\
\text { Passenger-Kms }\end{array}$ & 9.0 & 5.7 & 4.8 & 3.2 \\
\hline $\begin{array}{l}\text { Real World } \\
\text { GDP }\end{array}$ & 4.1 & 3.4 & 3.3 & 3.6 \\
\hline $\begin{array}{l}\text { GDP } \\
\text { Multipliers: }\end{array}$ & 1.4 & 1.4 & 1.3 & 0.7 \\
\hline $\begin{array}{l}\text { International } \\
\text { Tourist Arrivals }\end{array}$ & 2.2 & 1.7 & 1.5 & 0.9 \\
\hline $\begin{array}{l}\text { World } \\
\text { Passenger-Kms }\end{array}$ & & 0.96 & 1.38 & $1.47+$ \\
\hline $\begin{array}{l}\text { AVERAGE } \\
\text { VALUE: }\end{array}$ & 0.67 & 0.83 & 0.95 & $0.96+$ \\
\hline $\begin{array}{l}\text { International } \\
\text { Tourism } \\
\text { Spending as \% } \\
\text { World GDP }\end{array}$ & & & & \\
\hline $\begin{array}{l}\text { World Airline } \\
\text { Revenue as \% } \\
\text { World GDP }\end{array}$ & 0.61 & & & \\
\hline
\end{tabular}

Sources: WTO/ICAO/IATA/IMF

2004 data is provisional

$+2003 / 2000$

Table 2

International Tourist Arrivals by Mode of Transport 1990-2003(\%)

\begin{tabular}{|l|c|c|c|c|}
\hline & $\mathbf{1 9 9 0}$ & $\mathbf{1 9 9 5}$ & $\mathbf{2 0 0 0}$ & $\mathbf{2 0 0 3}$ \\
\hline Air & 35 & 38 & 40 & 42 \\
\hline Road & 52 & 52 & 50 & 46 \\
\hline Rail & 5 & 3 & 3 & 5 \\
\hline Water & 6 & 7 & 7 & 7 \\
\hline Not specified & 2 & 0 & 0 & 0 \\
\hline Total & 100 & 100 & 100 & 100 \\
\hline
\end{tabular}

Source: WTO 
Table 3: Characteristics of International Holidays Taken by UK Residents 1990-2004

\begin{tabular}{|l|l|l|l|l|}
\hline & $\begin{array}{l}\text { Air as \% } \\
\text { Total } \\
\text { International } \\
\text { Holiday } \\
\text { Trips }\end{array}$ & $\begin{array}{l}\text { Long-haul } \\
\text { as \% Total } \\
\text { Air } \\
\text { International } \\
\text { Holiday } \\
\text { Trips }\end{array}$ & $\begin{array}{l}\text { Package } \\
\text { Tours as \% } \\
\text { Total } \begin{array}{l}\text { Air } \\
\text { International } \\
\text { Holiday } \\
\text { Trips }\end{array}\end{array}$ & $\begin{array}{l}\text { Average } \\
\text { Length of } \\
\text { Stay of } \\
\text { International } \\
\text { orliday } \\
\text { Trips (days) }\end{array}$ \\
\hline $\mathbf{1 9 9 0}$ & 68 & 21 & 61 & 12.0 \\
\hline $\mathbf{1 9 9 1}$ & 66 & 22 & 58 & 11.9 \\
\hline $\mathbf{1 9 9 2}$ & 68 & 23 & 60 & 11.8 \\
\hline $\mathbf{1 9 9 3}$ & 72 & 24 & 61 & 11.6 \\
\hline $\mathbf{1 9 9 4}$ & 71 & 21 & 63 & 11.3 \\
\hline $\mathbf{1 9 9 5}$ & 73 & 22 & 62 & 10.9 \\
\hline $\mathbf{1 9 9 6}$ & 73 & 26 & 61 & 10.9 \\
\hline $\mathbf{1 9 9 7}$ & 74 & 24 & 61 & 10.4 \\
\hline $\mathbf{1 9 9 8}$ & 70 & 26 & 60 & 10.4 \\
\hline $\mathbf{1 9 9 9}$ & 72 & 25 & 59 & 10.5 \\
\hline $\mathbf{2 0 0 0}$ & 76 & 24 & 59 & 10.5 \\
\hline $\mathbf{2 0 0 1}$ & 77 & 20 & 57 & 10.3 \\
\hline $\mathbf{2 0 0 2}$ & 76 & 19 & 55 & 10.1 \\
\hline $\mathbf{2 0 0 3}$ & 79 & 18 & 50 & 10.2 \\
\hline $\mathbf{2 0 0 4}$ & 80 & 21 & 48 & n/a \\
\hline
\end{tabular}

Sources: IPS

2004 data is provisional 
Table 4: Long-Term Growth in Holiday Travel by UK Residents compared with Consumer Expenditure (CE) 1970-2004

\begin{tabular}{|l|c|c|c|c|}
\hline & $\mathbf{1 9 8 0 / 1 9 7 0}$ & $\mathbf{1 9 9 0 / 1 9 8 0}$ & $\mathbf{2 0 0 0 / 1 9 9 0}$ & $\mathbf{2 0 0 4 / 2 0 0 0}$ \\
\hline $\begin{array}{l}\text { Average Annual } \\
\text { Change (\%): }\end{array}$ & & & & \\
\hline $\begin{array}{l}\text { International } \\
\text { Air Holidays }\end{array}$ & 8.4 & 7.7 & 6.7 & 5.4 \\
\hline $\begin{array}{l}\text { All International } \\
\text { Holidays }\end{array}$ & 7.3 & 6.3 & 5.6 & 4.0 \\
\hline $\begin{array}{l}\text { All Holidays (4+ } \\
\text { nights) }\end{array}$ & 1.9 & 0.9 & 1.1 & $0.0+$ \\
\hline Real CE & 2.3 & 3.4 & 2.6 & 3.0 \\
\hline CE Multipliers: & 3.6 & 2.3 & 2.6 & 1.8 \\
\hline $\begin{array}{l}\text { International } \\
\text { Air Holidays }\end{array}$ & 3.2 & 1.8 & 2.1 & 1.4 \\
\hline $\begin{array}{l}\text { All International } \\
\text { Holidays }\end{array}$ & 0.8 & 0.3 & 0.4 & $0.0+$ \\
\hline $\begin{array}{l}\text { All Holidays (4+ } \\
\text { nights) }\end{array}$ & & 1.33 & 1.80 & $2.29^{*}$ \\
\hline $\begin{array}{l}\text { International } \\
\text { Air Holiday } \\
\text { Spending by } \\
\text { UK Residents } \\
\text { as\% CE }\end{array}$ & 0.64 & 1.94 & 2.17 & $2.09^{*}$ \\
\hline $\begin{array}{l}\text { UK Airline } \\
\text { Revenues as \% } \\
\text { CE }\end{array}$ & 1.79 & & & \\
\hline
\end{tabular}

Sources: IPS/BNTS/ONS

2004 data is provisional

$+2002 / 2000$

* 2003/2000 
Figure 1: Global Growth in International Tourism, Air Passenger-Kms and GDP

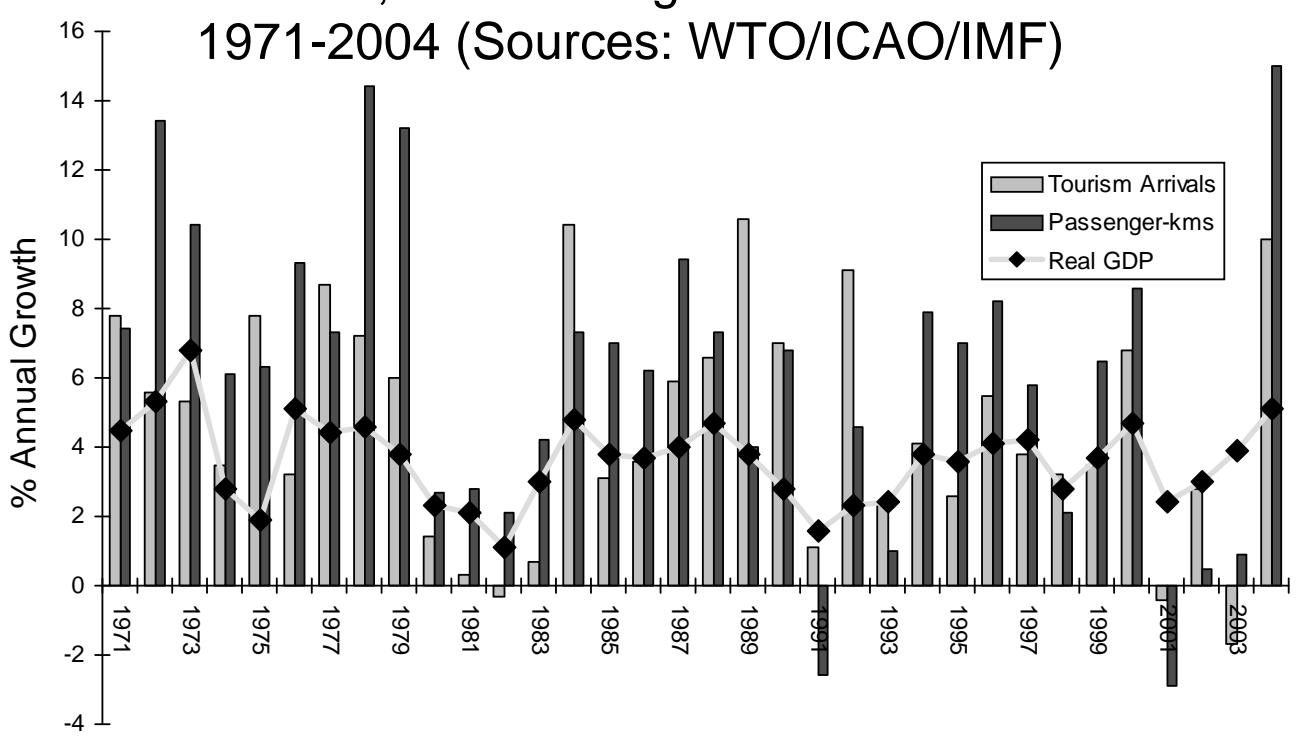

Figure 2:Tourism Spending and Airline

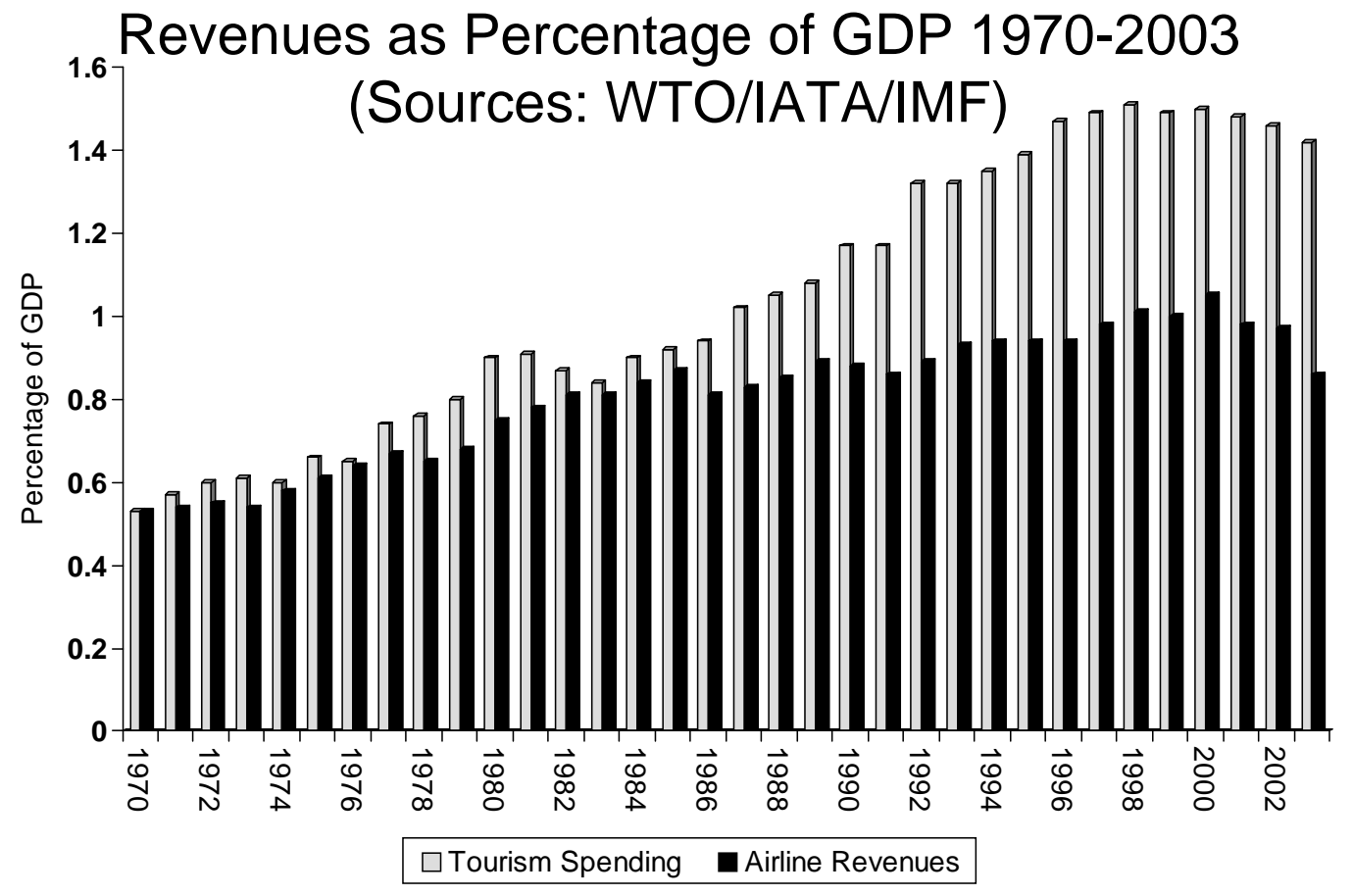


Figure 3: Tourism Spending by UK Residents \& UK Airline Revenues as Percentage of

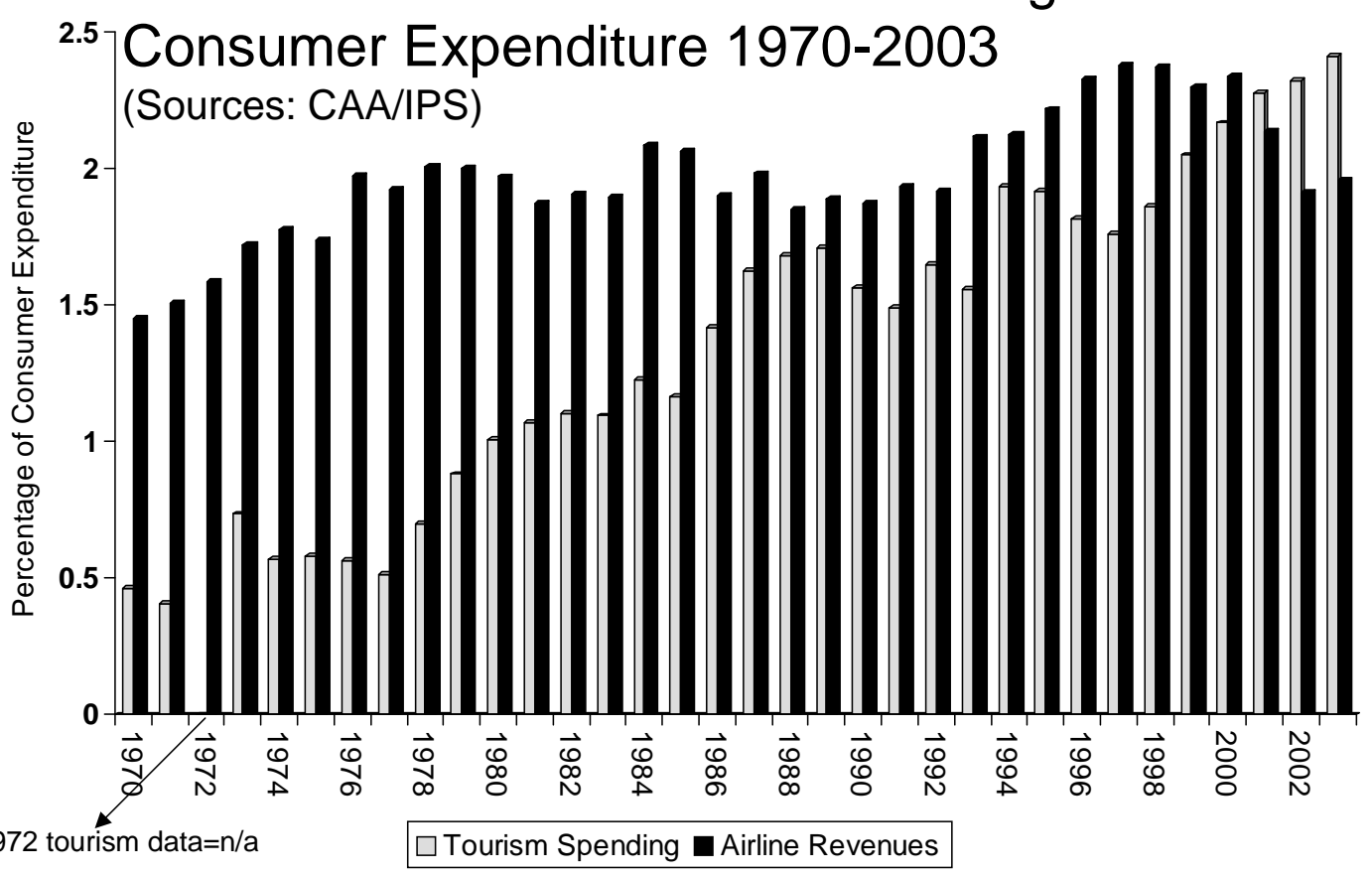

Figure 4: Leisure Trips at UK London Airports by UK Residents by Socio-Economic Group

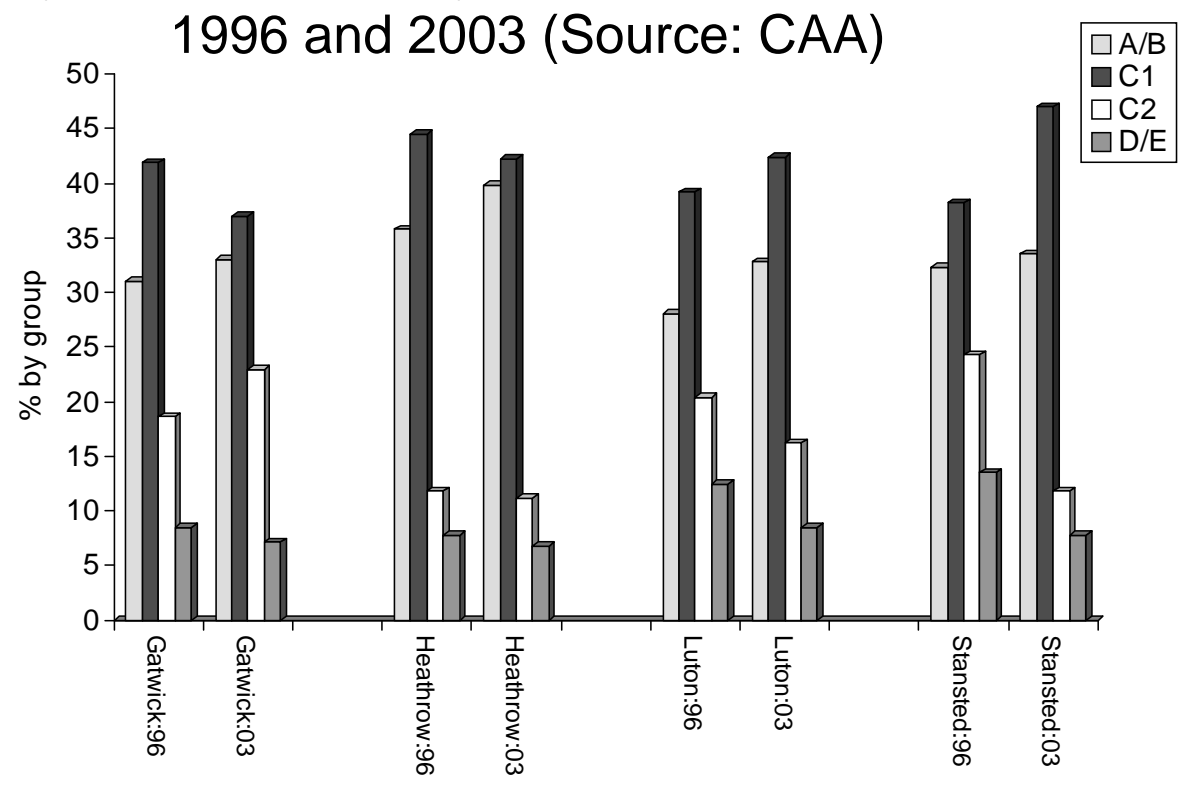

